\title{
HEREDITARY ELLIPTOCYTIC HAEMOLYTIC ANAEMIA
}

\author{
BY \\ E. K. BLACKBURN, ARThuR JORDAN, W. J. LYTLE, H. T. SWAN, \\ AND G. R. TUDHOPE \\ From the Departments of Haematology and Chemical Pathology and a Surgical Unit, Royal \\ Infirmary, Sheffield, and the Department of Therapeutics, University of Sheffield
}

(RECEIVED FOR PUBLICATION DECEMBER 13, 1957)

The erythrocytes of the camel are normally oval, whereas in man such cells are exceptional and comprise only 1 to $15 \%$ of the red cells of most normal people. A pathological increase in oval cells is found in some cases of iron deficiency and other microcytic anaemias, and there may commonly be more than $25 \%$ of oval cells among the erythrocytes in macrocytic anaemia (Florman and Wintrobe, 1938). Such symptomatic elliptocytosis (syn. ovalocytosis) is to be differentiated from hereditary elliptocytosis, which was first described by Dresbach in 1904. In the hereditary condition, rod forms are common in addition to the more oval elliptocytes, and altogether the abnormally shaped cells may constitute $50-90 \%$ of all the red cells (Wintrobe, 1956). Rod forms are not usually found among the elliptocytes of normal or anaemic blood. Hereditary elliptocytosis is transmitted as a simple Mendelian dominant, either sex being affected. It is said to occur in about $0.04 \%$ of the general American population (Wyandt, Bancroft, and Winship, 1941). Amongst affected people, the trait is said to be quite harmless in $88 \%$ of cases (Penfold and Lipscomb, 1943), but in the remainder haemolysis occurs with or without anaemia.

In the present paper an affected family is described, of which one member also suffered from haemolytic anaemia and was cured of this by splenectomy.

\section{Case Report}

A bookmaker, Homer S., aged 67 years, was admitted to hospital as an emergency on April 25, 1956. He gave a 12 hours' history of central abdominal pain radiating into the right iliac fossa. associated with nausea and anorexia, and a feeling of abdominal distension. He had had a similar, but milder. attack six months previously. which had settled on conservative treatment at home. His previous health had otherwise been good apart from an attack of typhoid fever associated with jaundice at the age of 28 years. A gangrenous appendix was removed under general anaesthesia and a drain inserted. Oxytetracycline was given intravenously for one day and orally for a further three days, until a total of $3.5 \mathrm{~g}$. had been given.

On the third day after operation jaundice developed. Examination of the blood at that time showed that most of the patient's erythrocytes were oval, with some rod forms (Fig. 1). After further investigations a diagnosis was made of hereditary elliptocytosis with haemolytic anaemia associated with splenomegaly. The detailed haematological findings which went to prove this diagnosis have been listed in Table I and in the subsequent text.

After operation, intermittent pyrexia up to $100^{\circ} \mathrm{F}$. lasted over six weeks. The jaundice persisted with some variation in intensity. The patient went home after two months with instructions to attend as an out-patient while investigations of haemolysis were

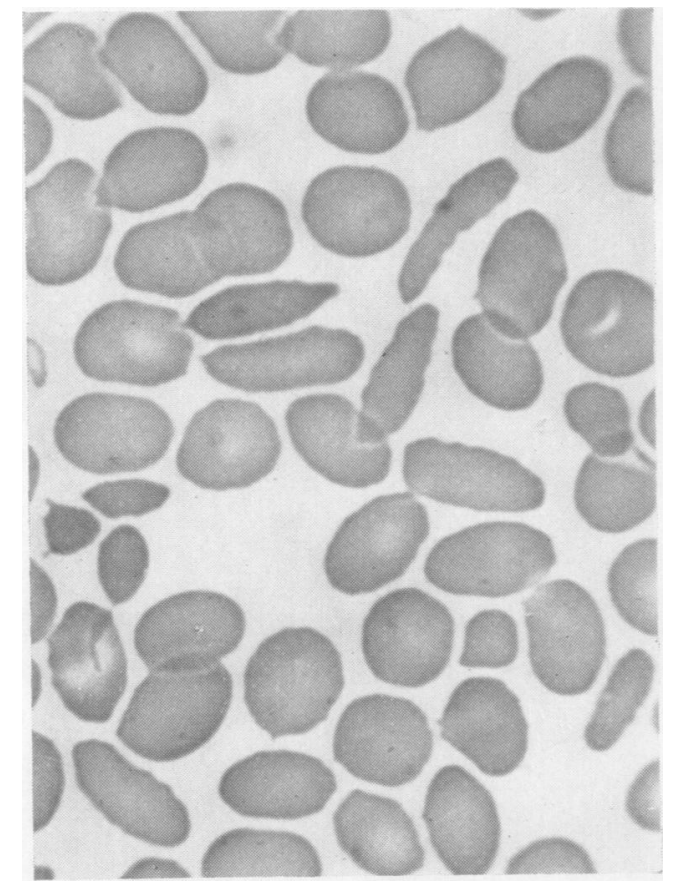

FIG. 1.-Peripheral blood ( - 750) showing elliptocytes and rod forms. 
TABLE I

LABORATORY FINDINGS IN EACH MEMBER OF THE FAMILY

\begin{tabular}{|c|c|c|c|c|c|c|c|c|c|c|c|c|c|c|}
\hline$\underset{\mathbf{Z}}{\stackrel{\mathbf{Z}}{\mathbf{Z}}}$ & $\stackrel{9}{\Xi ّ}$ & 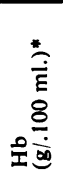 & 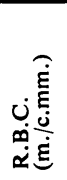 & 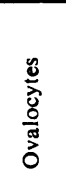 & 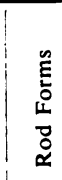 & 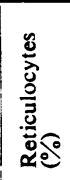 & $\begin{array}{l}3 \\
\dot{5} \\
\dot{0} \\
\dot{j} \\
\dot{0} \\
\dot{\Sigma}\end{array}$ & $\begin{array}{l}\int_{0}^{0} \\
\dot{j} \\
\dot{\Sigma} \\
\dot{\Sigma}\end{array}$ & 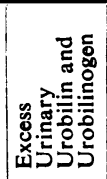 & 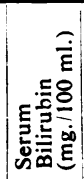 & 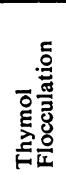 & 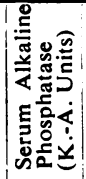 & 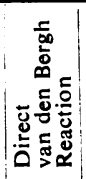 & 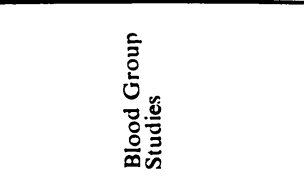 \\
\hline $\begin{array}{l}\text { Homer S. } \\
\text { A ppendi- } \\
\text { cectomy) } \\
\text { (Splenec- } \\
\text { tomy) }\end{array}$ & $\begin{array}{r}25 / 4 / 56 \\
28 / 4 / 56 \\
4 / 5 / 56 \\
11 / 5 / 56 \\
25 / 5 / 56 \\
2 / 6 / 56 \\
9 / 6 / 56 \\
18 / 6 / 56 \\
21 / 7 / 56 \\
23 / 7 / 56 \\
24 / 7 / 56 \\
28 / 7 / 56 \\
31 / 7 / 56 \\
13 / 8 / 56 \\
20 / 8 / 56 \\
17 / 6 / 57\end{array}$ & $\begin{array}{c}13 \cdot 8 \\
\\
8 \cdot 3 \\
7 \cdot 4 \\
10 \cdot 1 \\
10 \cdot 8 \\
11 \cdot 1 \\
14 \cdot 8 \\
15 \cdot 5 \\
15 \cdot 4 \\
16\end{array}$ & $\begin{array}{l}2 \cdot 5 \\
2 \cdot 8 \\
3 \cdot 2 \\
3 \cdot 5 \\
4 \cdot 5 \\
4 \cdot 5 \\
5 \cdot 0 \\
5 \cdot 5\end{array}$ & $\begin{array}{l}++ \\
++ \\
++ \\
++ \\
++ \\
++ \\
++\end{array}$ & $\begin{array}{l}+ \\
+ \\
+\end{array}$ & \begin{tabular}{|r}
30 \\
30 \\
12 \\
5 \\
7 \\
\\
6 \\
2 \\
1 \\
$<1$
\end{tabular} & 91 & $\begin{array}{l}35 \\
37\end{array}$ & $\begin{array}{c}+++ \\
++\end{array}$ & $\begin{array}{r}13 \cdot 2 \\
18 \cdot 7 \\
4 \cdot 3 \\
\\
\\
\end{array}$ & $\begin{array}{l}- \\
-\end{array}$ & $\begin{array}{r}7 \\
16 \\
11\end{array}$ & $=$ & $\begin{array}{l}\text { O, MNS, p, CDe cde. Cw } \\
-v e, \operatorname{Lu}(a-), \text { Kell -ve, } \\
\text { H }+ \text { ve, Le }(a+b-)\end{array}$ \\
\hline Jason S. & $186 / 56$ & $17 \cdot 5$ & $5 \cdot 5$ & ++ & + & $<1$ & 78 & 40 & + & $1 \cdot 3$ & - & 7 & \pm & $\begin{array}{l}A_{2}, \quad \text { MMS, Pw, CDe cde } \\
\text { Cw -ve, Lu }(a-), \text { Kell } \\
-v e, H+v e, L e(a+b-)\end{array}$ \\
\hline Penelope S. & 28656 & $14 \cdot 8$ & $4 \cdot 8$ & - & - & $<1$ & 81 & 38 & - & 0.6 & - & 24 & - & $\begin{array}{r}\text { O, MNS, p, CDe CDe, } \\
\text { Cw-ve, Lu }(\mathrm{a}-), \text { Kell } \\
-v e, H+v e, \text { Le }(a-b-)\end{array}$ \\
\hline Helen S. & 28,$6 ; 5$ & $14 \cdot 1$ & $4 \cdot 25$ & - & 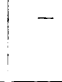 & $<1$ & 92 & 36 & - & 0.4 & - & 16 & - & $\begin{array}{l}A_{2}, \quad \text { MNS, P, CDe CDe. } \\
\text { Cw -ve, Lu }(a-), \text { Kell } \\
-v e, \text { Le }(a-b-)\end{array}$ \\
\hline Argus S. & $186 / 56$ & $16 \cdot 0$ & $5 \cdot 5$ & ++ & + & 2 & 82 & 38 & - & 1.7 & - & 9 & \pm & $\begin{array}{l}\text { A }_{2}, \quad \text { MNS, p, CDe cde } \\
\text { Cw - ve, Lu }(a-), \text { Kell } \\
\text { - ve, H +ve, Le }(a+b-)\end{array}$ \\
\hline Diana S. & $28 ' 6 / 56$ & $16 \cdot 3$ & $5 \cdot 0$ & - & 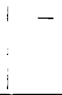 & $<1$ & 86 & 38 & - & 0.7 & - & 23 & - & $\begin{array}{l}\text { A, MMS, p, CDe cDE, } \\
\text { Cw-ve, Lu (a-), Kel } \\
-v e, H-v \in, \text { Le }(a-b-)\end{array}$ \\
\hline
\end{tabular}

* Hb $100 \%=14.8$ g. pe $: 103 \mathrm{ml}$. blood (oxyhaemoglobin-M.R.C. photometer).

being completed. When he was readmitted for splenectomy one month later, he was still slightly jaundiced and the edge of the spleen was felt $6.5 \mathrm{~cm}$. below the costal margin.

The spleen, which was surrounded by fine adhesions, was removed at operation on July 23, 1956. The gall bladder was distended and would not empty on manipulation. No gall stones were palpated and no accessory spleens were found. Fresh splenic smears showed erythrophagocytosis and an excess of granulocytes and nucleated red cells.

\section{Appearance and Histology of the Spleen}

The spleen weighed $537 \mathrm{~g}$. and measured $17 \times 10 \times$ $5 \mathrm{~cm}$. The cut surface resembled raw liver and the normal Malpighian pattern was indistinct. Histological examination revealed moderate congestion of the splenic pulp with marked prominence of the reticulo-endothelial cells, which lined the pulp spaces. Many instances of red cell ingestion were seen, and small haemosiderin granules abounded. There was no evidence of lymphoid hyperplasia, and the appearances were consistent with a non-neoplastic haemolytic process.

\section{Progress After Splenectomy}

Convalescence from splenectomy was rapid and uneventful. The jaundice disappeared within three days and has not since returned. The patient has had a sense of well-being such as he has not felt for a long time. Haematological investigations made five months after splenectomy showed a persistence of the characteristic oval and rod-shaped cells, but a complete absence of abnormal haemolysis. Details of these studies are included in Table $I$ and in the text.

\section{Red Cell Survival Studies Using ${ }^{51} \mathbf{C r}$}

Survival of red cells was studied in May, 1956, two months before splenectomy, and again in November, 1956, five months after operation. The same technique was used on each occasion.

$\mathrm{Na}_{2}{ }^{51} \mathrm{CrO}_{4}$, with an initial specific activity of $25 \mu \mathrm{c}$. $\mu \mathrm{g}$., was obtained in solution in isotonic saline from the Radiochemical Centre, Amersham, England. Fifteen millilitres of the patient's blood were added to $50 \mu \mathrm{c} .{ }^{51} \mathrm{Cr}$ and 500 units of heparin in a sterile glass container and the mixture was allowed to stand at room temperature for one hour. The red cells were then washed twice with cold, sterile, isotonic 


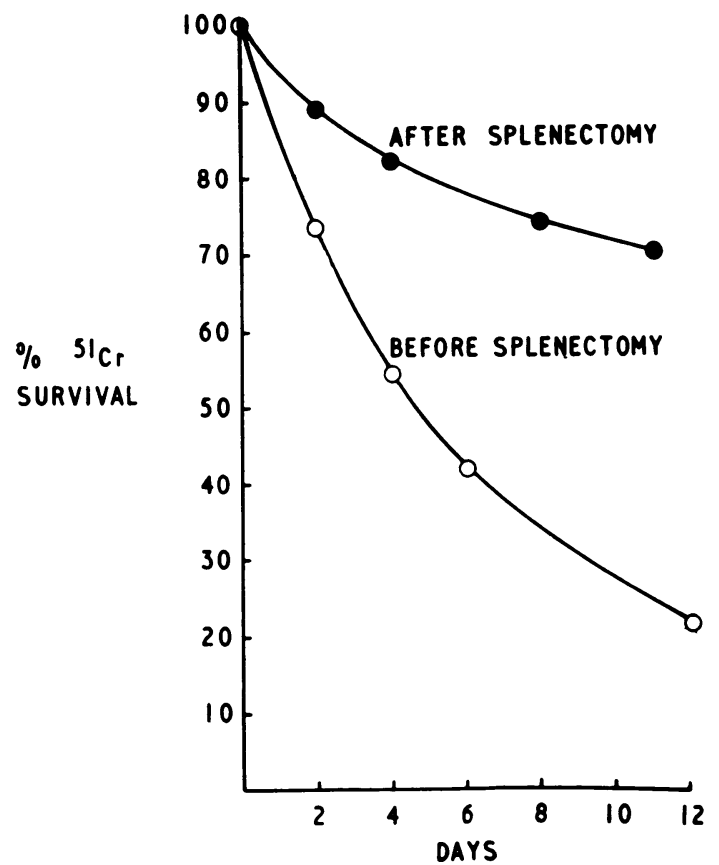

FIG. 2.-Survival of patient's own red cells labelled with ${ }^{51} \mathrm{Cr}$ before and after splenectomy.

saline, resuspended in saline, and $10 \mathrm{ml}$. of this suspension was injected intravenously. Standard dilutions were made in duplicate from what remained of the suspension; a dilution was also prepared from the supernatant fluid obtained by centrifugation of the cell suspension.

One blood sample was taken from the opposite arm 30 minutes after the injection, and four further blood samples were taken at intervals of two to six days. The haematocrits of all blood samples and of the labelled red cell suspension were measured in duplicate in Wintrobe tubes centrifuged at 3,000 r.p.m., at a radius of $15 \mathrm{~cm}$. for 55 minutes. All readings were corrected for trapped plasma using the data of Chaplin and Mollison (1952). After removing enough blood for haematocrit measurement, the remainder of each sample was haemolysed with saponin.

The radioactivity of all haemolysed blood samples and standard dilutions was measured in a scintillation counter ("Ekco," type N550), 6,000 counts being obtained in all cases. Correction was made for radioactive decay and for variation in the characteristics of the counting apparatus by reference to a standard dilution of ${ }^{51} \mathrm{Cr}$. The radioactivity of blood samples was expressed as counts per minute per millilitre of red cells, by dividing the counts per minute for whole blood by the corrected haematocrit. These values were then expressed as percentages of the radioactivity of the initial sample withdrawn 30 minutes after the injection of labelled cells.

In the study carried out before splenectomy, the total red cell volume was finally measured on the twelfth day by the injection of the patient's red cells labelled with ${ }^{32} \mathrm{P}$, the blood samples and standard dilutions being counted on a G.M. liquid counter (Veall, 1948). Total red cell volume measurements at the beginning and end of the study before splenectomy, and at the beginning of the subsequent study, are shown in Table II ; in the second study the red cell volume was assumed to be constant during the period of observation and was determined only once.

TABLE II

TOTAL RED CELL VOLUME AND HALF-TIME OF SURVIVAL OF ${ }^{51} \mathrm{Cr}$ BEFORE AND AFTER SPLENECTOMY

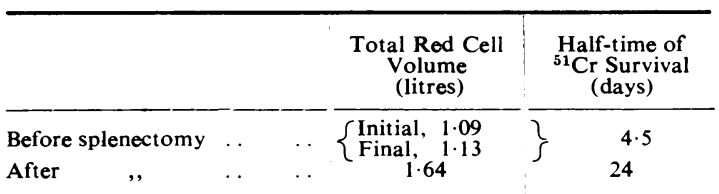

The ${ }^{51} \mathrm{Cr}$ survival curves before and after splenectomy are shown in Fig. 2. The half-time of ${ }^{5} \mathrm{Cr}$ survival (Table II) before splenectomy was reduced to 4.5 days, whereas extrapolation of the curve after splenectomy showed a half-time of survival of 24 days, which is within the normal range (Read, Wilson, and Gardner, 1954 ; Mollison and Veall, 1955). No correction has been made for total red cell changes during the first study. The observed change in total red cell volume is slight and of doubtful significance, particularly as the second measurement utilized ${ }^{32} \mathrm{P}$ labelled red cells, a method known to give occasional over-estimates of red cell volume (Mollison and Veall, 1955).

From the observed ${ }^{51} \mathrm{Cr}$ survival before splenectomy, the "true survival" of red cells was calculated as suggested by Jones and Mollison (1956), using the data for normal ${ }^{51} \mathrm{Cr}$ survival of Mollison and Veall (1955). The true survival was then plotted (Fig. 3) and the tangent to the initial slope extrapolated to the time axis to give an estimate of mean red cell life (Dornhorst, 1951). Before splenectomy, the mean cell life was nine days. After splenectomy, the normal half-time of ${ }^{51} \mathrm{Cr}$ survival of 24 days can be taken to indicate a normal red cell life of about 110 days (Mollison and Veall, 1955; Jones and Mollison, 1956).

\section{Other Investigations Made before Splenectomy}

The saline osmotic fragility of the red cells (Dacie, 1956a) was slightly increased (control 0.44-0.34\% saline, patient $0.56-0.40^{\circ} \%$ saline). Incubation of such suspensions at $37^{\circ} \mathrm{C}$. for 24 hours (Dacie, 1956b) accentuated their difference from the control. Autohaemolysis tests, where whole blood is incubated at $37^{\circ} \mathrm{C}$. for 24 and 48 hours (Dacie, 1956c), and the mechanical red cell fragility (Dacie, 1956d) were within the normal range. Bone marrow examination showed an active normoblastic reaction, but no normoblasts were elliptical. Reticulocytes were mostly round, so that the elliptocytes were fully apparent 


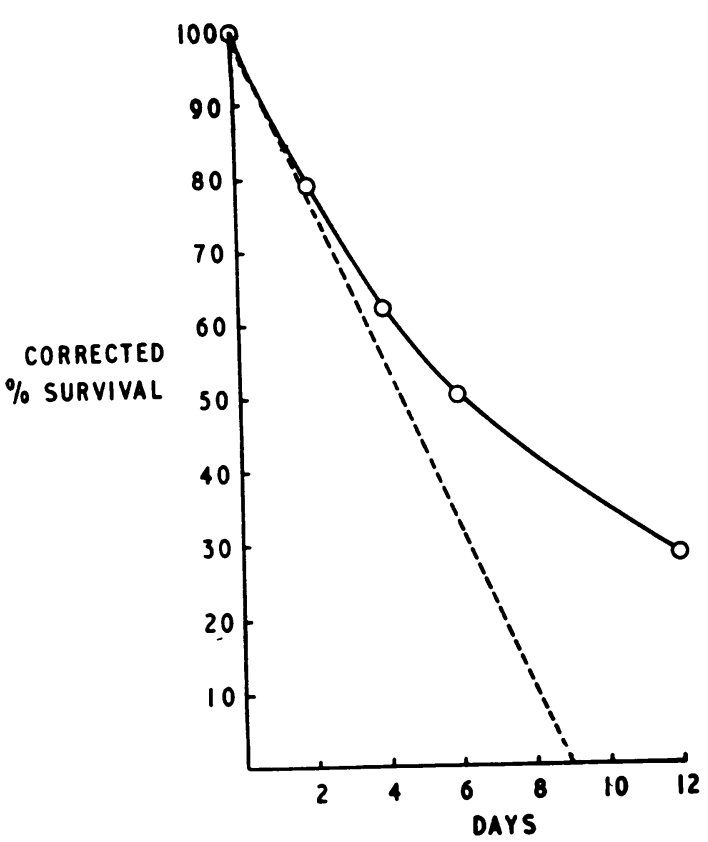

FIG. 3.-The "true survival" of red cells before splenectomy.

only at the erythrocyte level of maturity. Examination of wet sealed films confirmed the elliptocytosis and did not show true spherocytes. The serial dilution direct antiglobulin test was negative: no auto- or pan-haemagglutinins or haemolysins were detected in saline or in albumin at $4^{\circ} \mathrm{C}$., $18^{\circ} \mathrm{C}$., and $37^{\circ} \mathrm{C}$.: the Donath-Landsteiner test was negative: the acid-serum haemolysis test was negative: no immune Rhesus or Kell antibodies were detected in saline or albumin or by using the indirect antiglobulin technique. There was no evidence of auto-immunization. An intravenous cholecystogram outlined the common bile duct, but the gall-bladder was not seen. No calculi were seen.

After splenectomy the haemoglobin was examined electrophoretically and did not show the presence of any abnormal haemoglobin. The saline osmotic fragility of the red cells was estimated again and was still slightly increased (control $0.48-0.34 \%$ saline, patient $0.54-0.38 \%$ saline).

\section{Family Studies}

Five direct descendants of the patient (Homer S.) were studied. His two sons, Jason, aged 41 years, and Argus, aged 39 years, both showed the same elliptocytosis as their father, but they supplied no more than suggestive evidence of subclinical haemolysis (Table I). Neither son had felt in any way unwell and there had been no clinical jaundice at any time, nor was there detectable splenomegaly. The saline osmotic fragilities of their peripheral red cells were normal.
The two daughters of Jason, Penelope, aged 10 years, and Helen, aged 7 years, were studied at the same time as their father. They showed no elliptocytosis and appeared normal in all respects apart from a serum alkaline phosphatase activity in Penelope of 24 King-Armstrong units of doubtful interpretation (Table I). There was no history of jaundice.

Diana, aged 9 years, the daughter of Argus, also showed no elliptocytosis and was well; she had a serum alkaline phosphatase activity of 23 KingArmstrong units. There was no history of jaundice.

\section{Discussion}

The factors which determine the unusual shape of the erythrocytes in hereditary elliptocytosis are unknown. There are apparently no abnormalities in the haemoglobin as determined by the alkaline denaturation test and by haemoglobin electrophoresis (Letman, 1955), but Selwyn (1953) has shown that glucose reduces the amount of erythrocyte autohaemolysis in vitro to a lesser degree than in the normal. The mean corpuscular volume and the mean corpuscular haemoglobin concentration of elliptocytes have usually been reported as normal. This is also the case in the three affected members of this family.

Haemolytic anaemia with elliptocytosis has been described where the latter trait was present in both parents (Wyandt et al., 1941). The frequency of such a union must be very rare. Where the inheritance of the elliptocytosis comes from only one parent, most patients remain free from apparent haemolysis, but some develop a haemolytic anaemia (Motulsky, Singer, Crosby, and Smith, 1954 ; Lipton, 1955). It is not possible to investigate the antecedent heredity in our patient, both his parents being dead.

Goodall, Hendry, Lawler, and Stephen (1953) have found evidence for linkage of the gene for elliptocytosis to the cde (Rhesus blood group) combination of antigens. Our findings lend support to this work because the cde combination is present in the propositor and his two sons, who all have elliptocytosis, and not in the three granddaughters, who have normal peripheral blood.

Our studies support the view that the nucleated precursors of elliptocytes are round, the anomaly first making its appearance in the reticulocyte stage (Schartum-Hansen, 1935). Letman (1955) noted an increase in saline osmotic fragility following splenectomy in a case of hereditary elliptocytosis with haemolytic anaemia. Here the fragility was slightly abnormal before splenectomy, but was not increased by splenectomy. The saline osmotic fragility of the elliptocytes of the two sons appeared to be within normal limits. 
It is quite possible that subclinical haemolysis had been present for some time, perhaps years, before the patient was ever seen in hospital, but it seems probable on clinical evidence that haemolysis was at least greatly increased, even if not initiated, by some factor operating at the time of his admission for appendicectomy. The rate of haemolysis appeared to have diminished three months later. Jaundice was then still apparent clinically, but disappeared immediately after splenectomy.

There are certain features concerning the two sons which are suggestive of slightly abnormal haemolysis. Both have a raised serum bilirubin level, a positive direct van den Bergh test, and one has a slight excess of urobilinogen in the urine. The presence of abnormal haemolysis could be proved only by differential cell agglutination survival studies introduced by Ashby (1919) or by radioactive labelling of red cells.

Several studies have been made of red cell survival in hereditary elliptocytosis without anaemia (Trinick, 1948; Berlin and Hedenstedt, 1952; Motulsky et al., 1954). Most recent studies have shown normal survival of the elliptocytes when transfused into normal subjects. One patient, reported by Motulsky and his associates (1954), had a shortened red cell survival time of 45 days and had also other evidence of haemolysis, but was not anaemic.

Information about red cell survival in hereditary elliptocytic haemolytic anaemia is scanty. Splenectomy has been reported to be of benefit in several cases (Wilson and Long, 1953; Dacie, Mollison, Richardson, Selwyn, and Shapiro, 1953). In the present case the shortened mean cell survival time had returned to normal five months after operation, and splenectomy was clearly of benefit.

\section{Summary}

A case is described of hereditary elliptocytosis with an associated haemolytic anaemia which responded well to splenectomy. The degree of haemolysis had increased at the time of surgery for acute appendicitis. The red cell survival time using ${ }^{51} \mathrm{Cr}$ was short before splenectomy, but normal after operation. The saline osmotic fragility was slightly increased, but was not affected by splenectomy. No obvious change was noted in the appearance of the elliptocytes after operation.

The two sons of the patient have elliptocytosis without anaemia. The father and sons all have the cde combination of antigens, which is absent in three granddaughters, who show no elliptocytosis.

We are indebted to Dr. C. C. Bowley, Dr. I. Dunsford, and Dr. G. Owen of the Regional Blood Transfusion Centre, Sheffield, for the blood group studies and for confirming our serological findings; to Dr. R. A. Caldwell for the histological report ; to Miss P. Hall, B.Sc., Miss Mary S. Mackay, B.Sc., and Mr. J. Monaghan, F.I.M.L.T. for laboratory assistance, to Mr. J. F. V. Larway and Mr. J. Hainsworth for the photograph, and to the family for their co-operation.

We are grateful to Professor G. M. Wilson for reading and criticizing the manuscript. E. K. B. and G. R. T. thank the Board of Governors of the United Sheffield Hospitals for research grants through their Endowment Fund.

\section{REFERENCES}

Ashby, W. (1919). J. exp. Med., 29, 267.

Berlin, R., and Hedenstedt, S. (1952). Acta med. scand., 143, 273.

Chaplin, H., Jr., and Mollison, P. L. (1952). Blood, 7, 1227.

Dacie, J. V. (1956a). Practical Haematology, 2nd ed., p. $94 . \quad$ J. and A. Churchill, London.

(1956b). Ibid., p. 98.

- (1956c). Ibid., p. 99.

(1956d). Ibid., p. 101.

- Mollison, P. L., Richardson, N., Selwyn, J. G., and Shapiro, L. (1953). Quart. J. Med., 22, 79.

Dornhorst, A. C. (1951). Blood, 6, 1284.

Dresbach, M. (1904). Science, 19, 469.

Florman, A. L., and Wintrobe, M. M. (1938). Bull. Johns Hopk. Hosp., 63, 209.

Goodall, H. B., Hendry, D. W. W., Lawler, S. D., and Stephen, S. A. (1953). Ann. Eugen. (Lond.), 17, 272.

Jones, N. C. H., and Mollison, P. L. (1956). Clin. Sci., 15, 207.

Letman, H. (1955). Acta med. scand., 151, 41.

Lipton, E. L. (1955). Pediatrics, 15, 67.

Mollison, P. L., and Veall, N. (1955). Brit. J. Haemat., 1, 62.

Motulsky, A. G., Singer, K., Crosby, W. H., and Smith, V. (1954). Blood, $9,57$.

Penfold, J. B., and Lipscomb, J. M. (1943). Quart. J. Med., 12, 157.

Read, R. C., Wilson, G. M., and Gardner, F. H. (1954). Amer. J med. Sci., 228, 40.

Schartum-Hansen, H. (1935). Acta med. scand., 86, 348.

Selwyn, J. G. (1953). Unpublished observations quoted by Dacie, J. V. (1954). The Haemolvtic Anaemias, Congenital and Acquired, p. 100 . J. and A. Churchill, London.

Trinick, R. H. (1948). Lancet, 1, 963.

Veall, N. (1948). Brit. J. Radiol., 21, 347.

Wilson, H. E., and Long, M. J. (1953). Amer. J. Med., 14, 534.

Wintrobe, M. M. (1956). Clinical Hematology, 4th ed., p. 96. Henry Kimpton, London.

Wyandt, H.. Bancroft, P. M., and Winship, T. O. (1941). Arch. intern. iled., 68, 1043 . 